\title{
Development of RAP Tag, a Novel Tagging System for Protein Detection and Purification
}

\author{
Yuki Fujii,, Mika K. Kaneko, Satoshi Ogasawara, Shinji Yamada, Miyuki Yanaka,, Takuro Nakamura, \\ Noriko Saidoh, Kanae Yoshida, Ryusuke Honma, and Yukinari Kato ${ }^{1,2}$
}

Affinity tag systems, possessing high affinity and specificity, are useful for protein detection and purification. The most suitable tag for a particular purpose should be selected from many available affinity tag systems. In this study, we developed a novel affinity tag called the "RAP tag" system, which comprises a mouse antirat podoplanin monoclonal antibody (clone PMab-2) and the RAP tag (DMVNPGLEDRIE). This system is useful not only for protein detection in Western blotting, flow cytometry, and sandwich enzyme-linked immunosorbent assay, but also for protein purification.

Keywords: monoclonal antibody, RAP tag, affinity tag, protein purification, podoplanin

\section{Introduction}

A FFINITY TAG SYSTEMS, which are useful for protein purification and detection, are classified into "peptide tags" and "protein tags." Protein tags, including glutathioneS-transferase tag, ${ }^{(1)}$ maltose-binding protein tag, ${ }^{(2)} \mathrm{Fc}$ tag of immunoglobulin, ${ }^{(3)}$ and green fluorescent protein tag, ${ }^{(4)}$ have numerous advantages because they are useful for protein expression in the soluble fraction or are easily detected using monoclonal antibodies (mAbs). In contrast, protein tags sometimes affect the character of the target proteins if they are large in size $(>25 \mathrm{kDa})$; therefore, their removal is necessary before any protein analysis. Peptide tags are less likely to affect the structure and function of target proteins because of their small size (typically $1-2 \mathrm{kDa}$ ); therefore, it is not always necessary to remove the tag portion for protein analysis.

The most appropriate peptide tag system can be selected from many available peptide tags, such as FLAG tag, ${ }^{(5)}$ TARGET tag, ${ }^{(6)} \mathrm{PA}$ tag, ${ }^{(7-16)}$ and MAP tag, ${ }^{(17-20)}$ among many others. (21-23) These systems sometimes have disadvantages, such as low specificity, low affinity, or difficulty in achieving protein elution. Therefore, we need to develop further affinity tag systems to overcome these disadvantages of established affinity tag systems.

We previously developed a mouse mAb (clone PMab-2) against the platelet aggregation-stimulating domain of rat podoplanin. ${ }^{(24)}$ Podoplanin is a type I transmembrane protein, which is highly expressed in many normal cells and cancer cells, and is involved in tumor-induced platelet aggregation by binding to CLEC-2 on platelets. ${ }^{(3,25-33)}$ Because PMab-2 possesses high affinity and specificity against rat podoplanin, ${ }^{(24)}$ it was expected to be useful as an antitag antibody. Herein, we developed a novel affinity tag system, the "RAP tag", system, using PMab-2 mAb.

\section{Results and Discussion}

We first investigated the binding affinity between PMab-2 $\mathrm{mAb}$ and RAP tag (DMVNPGLEDRIE) using the BIAcore X100 system. Curve fitting showed the affinity for PMab-2RAP tag interaction: $k_{a}=2.0 \times 10^{5} \mathrm{M}^{-1} \mathrm{~s}^{-1}, k_{d}=2.0 \times 10^{-3} \mathrm{~s}^{-1}$, and $K_{\mathrm{D}}=9.7 \times 10^{-9} \mathrm{M}$, indicating that PMab-2 showed moderate affinity toward the RAP tag. Next, we examined whether the RAP tag system is useful for several protein detection systems. As depicted in Figure 1A, PMab-2 showed a strong single band corresponding to the molecular weight of human epidermal growth factor receptor (EGFR) with RAP tag $(\sim 170 \mathrm{kDa})$ in Western blot analysis. Transfectants of EGFR were established previously. ${ }^{(17)}$ PMab-2 did not show any nonspecific bands in CHO-K1 and LN229 cells, indicating that PMab-2 is very specific to the RAP tag. PMab-2 reacted with the EGFR with the N-terminal RAP tag, which was expressed in CHO-K1 cells in flow cytometry (Fig. 1B, left). As a positive control, antihuman EGFR mAbs (EMab-

\footnotetext{
${ }^{1}$ Department of Regional Innovation, Tohoku University Graduate School of Medicine, Sendai, Japan.

${ }^{2}$ New Industry Creation Hatchery Center, Tohoku University, Sendai, Japan.
}

(C) Yuki Fujii et al., 2017; Published by Mary Ann Liebert, Inc. This Open Access article is distributed under the terms of the Creative Commons License (http://creativecommons.org/licenses/by/4.0), which permits unrestricted use, distribution, and reproduction in any medium, provided the original work is properly credited. 


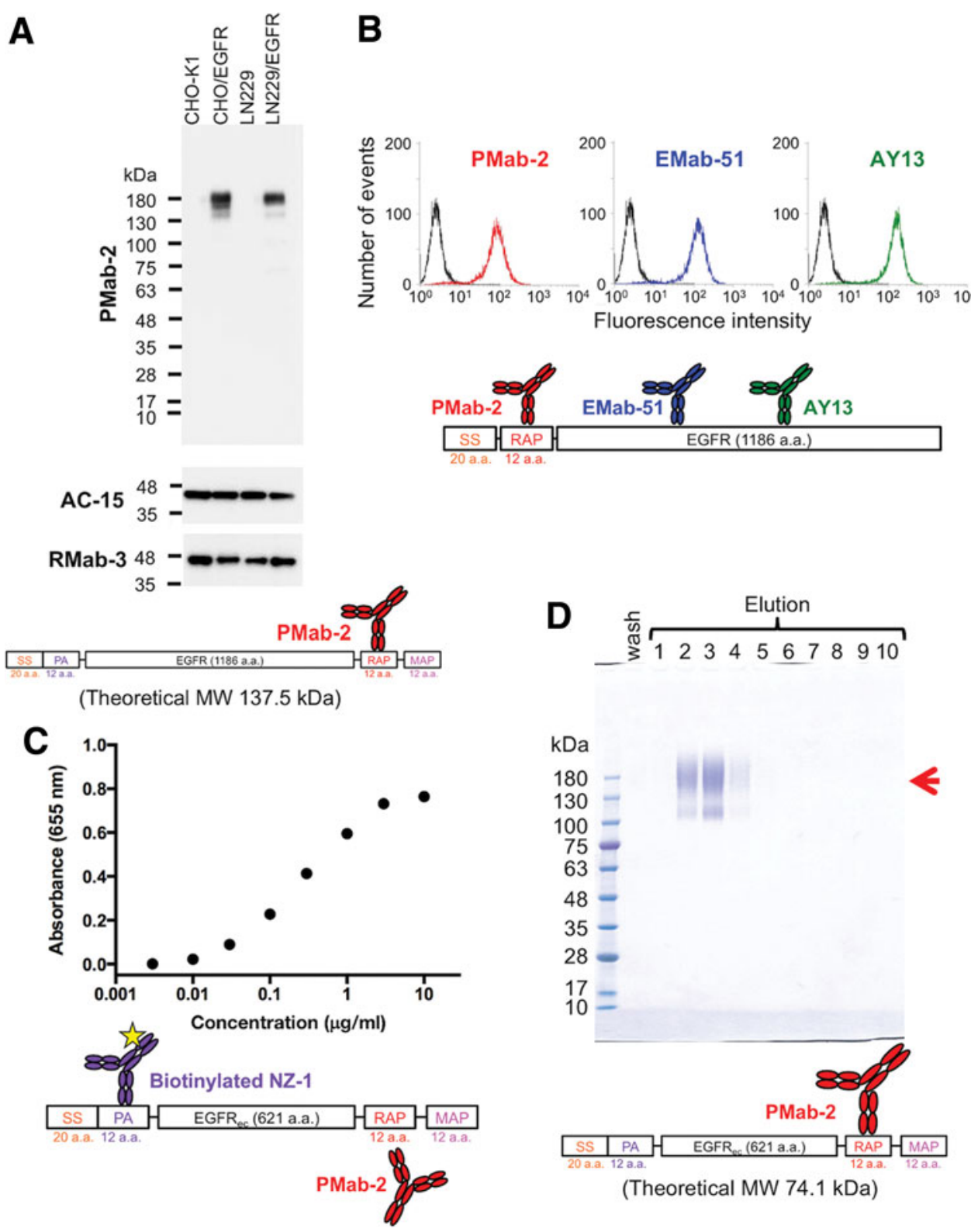

FIG. 1. Detection and purification of RAP-tagged EGFR by the RAP tag system. (A) Western blot analysis of RAP-tagged EGFR using anti-RAP tag mAb, PMab-2. Total cell lysates (CHO-K1, CHO/EGFR, LN229, and LN229/EGFR) were electrophoresed under reducing conditions using 5\%-20\% SDS-PAGE gel and transferred to a membrane. The membrane containing the same amount of lysate was immunoblotted using $1 \mu \mathrm{g} / \mathrm{mL}$ PMab-2 (anti-RAP tag), AC-15 (anti- $\beta$-actin), or RMab-3 (anti-IDH1) for 30 minutes, and incubated with a peroxidase-conjugated secondary antibody specific for mouse IgG. (B) Flow cytometric analysis of RAP-tagged membrane protein. Two antihuman EGFR mAbs (clones: EMab-51 and AY13) were used in this study. EMab-51 $\left(\operatorname{IgG}_{1}, \kappa\right)$ was established in our laboratory. AY13 $\left(\operatorname{IgG}_{1}, \kappa\right)$ was purchased from BioLegend (San Diego, CA). CHO-K1 cells and CHO/RAP-EGFR were treated with $1 \mu \mathrm{g} / \mathrm{mL}$ PMab-2, EMab-51, or AY13 for 30 minutes at $4^{\circ} \mathrm{C}$, followed by 1:1000 diluted Oregon Green 488 goat antimouse IgG (Thermo Fisher Scientific, Inc., Waltham, MA). Fluorescence data were collected using a Cell Analyzer EC800 (Sony Corp., Tokyo, Japan). (C) Sandwich ELISA of RAP-tagged protein. PMab-2 was immobilized at a concentration of $10 \mu \mathrm{g} / \mathrm{mL}$ for 30 minutes. After blocking with $1 \%$ bovine serum albumin in $0.05 \%$ Tween 20/phosphate-buffered saline (pH 7.4), recombinant PA-EGFR ${ }_{\text {ec }}-\mathrm{RAP}_{\text {- }}$ MAP was added at a concentration from $3 \mathrm{ng} / \mathrm{mL}$ to $10 \mu \mathrm{g} / \mathrm{mL}$ and was incubated overnight. After washing, the plates were incubated with $0.5 \mu \mathrm{g} / \mathrm{mL}$ biotinylated NZ-1 (anti-PA tag), followed by 1:5000 diluted peroxidase-conjugated streptavidin (GE Healthcare Bio-Sciences, Pittsburgh, PA). The enzymatic reaction was performed using 1-Step Ultra TMB-ELISA (Thermo Fisher Scientific, Inc.). The optical density was measured at $655 \mathrm{~nm}$ using an iMark microplate reader (Bio-Rad Laboratories, Inc., Berkeley, CA). Data are means of four replicates \pm SEM. (D) Purification of soluble ectodomain fragment of EGFR $\left(E G_{F}\right)$. LN229/EGFR ${ }_{\mathrm{ec}}$ was cultured and $1 \mathrm{~L}$ of culture supernatant was harvested. The filtered supernatant was passed through PMab-2-Sepharose ( $4 \mathrm{~mL}$ bed volume), and the same process was repeated three times. The beads were then washed with $80 \mathrm{~mL}$ of Tris-buffered saline (TBS; $\mathrm{pH}$ 7.5) and eluted with $0.1 \mathrm{mg} / \mathrm{mL}$ epitope peptide in a step-wise manner $(4 \mathrm{~mL} \times 10)$. Ten microliters of the 5 th of 5 washes in TBS (wash) and 10 peptide-eluted fractions (lanes 1-10) during the column chromatography were subjected to 5\%-20\% SDS-PAGE under reducing conditions and were stained with Coomassie brilliant blue. Arrow: $\mathrm{EGFR}_{\mathrm{ec}}$. ec, ectodomain; EGFR, epidermal growth factor receptor; ELISA, enzyme-linked immunosorbent assay; mAb, monoclonal antibody; SDS-PAGE, sodium dodecyl sulfate polyacrylamide gel electrophoresis; SS, signal sequence. 
51 and AY13) recognized CHO-K1/EGFR (Fig. 1B, middle and right). We further investigated whether the RAP tag system is useful in sandwich enzyme-linked immunosorbent assay (ELISA). PMab-2 was immobilized, and the soluble ectodomain fragment of EGFR (EGFR ${ }_{\mathrm{ec}}$ ) with RAP tag was added at a concentration from $3 \mathrm{ng} / \mathrm{mL}$ to $10 \mu \mathrm{g} / \mathrm{mL}$ and detected by biotinylated NZ-1. As shown in Figure 1C, EGFR was detected in a dose-dependent manner. These results indicate that the RAP tag system is useful for Western blotting, flow cytometry, and sandwich ELISA.

Next, we purified three different RAP-tagged proteins using the RAP tag system. The EGFR $\mathrm{ec}_{\mathrm{ec}}$ and the soluble ectodomain fragment of human epidermal growth factor receptor $2\left(\mathrm{HER} 2_{\mathrm{ec}}\right)$ were expressed in LN229 and were purified from the culture supernatant (Fig. 1D and Supplementary Fig. S1A). The fragment of $\alpha$-thalassemia/mentalretardation-syndrome-X-linked (ATRXepi; $\sim 25 \mathrm{kDa}$ ) was expressed in Escherichia coli and purified from the soluble fraction of the bacterial lysate (Supplementary Fig. S1B). All RAP-tagged proteins were captured onto PMab-2-Sepharose and eluted from the resin by a solution containing $0.1 \mathrm{mg} / \mathrm{mL}$ free epitope peptide (GDDMVNPGLEDRIE). These proteins were efficiently eluted using the RAP tag peptide because of the high dissociation constant for PMab-2-RAP tag interaction. EGFR $\mathrm{ec}_{\mathrm{ec}}$ and HER $2_{\mathrm{ec}}$ were eluted in elution fractions 2$4\left(\right.$ EGFR $\left._{\mathrm{ec}}\right)$ or 2-3 (HER2 $2_{\mathrm{ec}}$ ) at a high concentration (Fig. 1D and Supplementary Fig. S1A). EGFR ${ }_{\mathrm{ec}}$ and HER $2_{\mathrm{ec}}$ are highly glycosylated $^{(34,35)}$; therefore, they were electrophoresed at a "heavier" position compared with that suggested by the theoretical molecular weight. ATRXepi was eluted in elution fractions 2-10 (Supplementary Fig. S1B). These purified proteins showed high purity and were ready for use in downstream experiments without further purification, indicating that the RAP tag system is a powerful protein purification tool.

In conclusion, we successfully developed a novel affinity tagging system, "RAP tag," by employing a unique mAb PMab-2 against rat podoplanin. The RAP tag system could be advantageous for protein purification and detection in the field of protein science.

\section{Acknowledgments}

This work was supported mainly by the Basic Science and Platform Technology Program for Innovative Biological Medicine from Japan Agency for Medical Research and Development, AMED (Y.K.). This work was also supported in part by the Platform for Drug Discovery, Informatics, and Structural Life Science (PDIS) from AMED (Y.K.), by Project for utilizing glycans in the development of innovative drug discovery technologies from AMED (Y.K.), by Translational Research Network Program from AMED (Y.K.), by the Regional Innovation Strategy Support Program from the Ministry of Education, Culture, Sports, Science and Technology (MEXT) of Japan (Y.K.), by JSPS KAKENHI Grant Numbers 26440019 (M.K.K.) and 16K10748 (Y.K.). This work was performed, in part, under the Cooperative Research Program of Institute for Protein Research, Osaka University, CR-16-05. The authors thank Enago (www.enago.jp) for the English language review.

\section{Author Disclosure Statement}

No competing financial interests exist.

\section{References}

1. Smith DB, and Johnson KS: Single-step purification of polypeptides expressed in Escherichia coli as fusions with glutathione S-transferase. Gene 1988;67:31-40.

2. Diguan C, Li P, Riggs PD, and Inouye H: Vectors that facilitate the expression and purification of foreign peptides in Escherichia coli by fusion to maltose-binding protein. Gene 1988;67:21-30.

3. Kato Y, Kaneko MK, Kunita A, Ito H, Kameyama A, Ogasawara S, Matsuura N, Hasegawa Y, Suzuki-Inoue K, Inoue O, Ozaki Y, and Narimatsu H: Molecular analysis of the pathophysiological binding of the platelet aggregationinducing factor podoplanin to the C-type lectin-like receptor CLEC-2. Cancer Sci 2008;99:54-61.

4. Wang S, and Hazelrigg T: Implications for bcd mRNA localization from spatial distribution of exu protein in Drosophila oogenesis. Nature 1994;369:400-403.

5. Hopp TP, Prickett KS, Price VL, Libby RT, March CJ, Cerretti DP, Urdal DL, and Conlon PJ: A short polypeptide marker sequence useful for recombinant protein identification and purification. Nat Biotechnol 1988;6:1204-1210.

6. Tabata S, Nampo M, Mihara E, Tamura-Kawakami K, Fujii $\mathrm{I}$, and Takagi J: A rapid screening method for cell lines producing singly-tagged recombinant proteins using the “TARGET tag" system. J Proteomics 2010;73:1777-1785.

7. Fujii Y, Kaneko M, Neyazaki M, Nogi T, Kato Y, and Takagi J: PA tag: A versatile protein tagging system using a super high affinity antibody against a dodecapeptide derived from human podoplanin. Protein Expr Purif 2014;95: 240-247.

8. Fujii Y, Matsunaga Y, Arimori T, Kitago Y, Ogasawara S, Kaneko MK, Kato Y, and Takagi J: Tailored placement of a turn-forming PA tag into the structured domain of a protein to probe its conformational state. J Cell Sci 2016;129: $1512-1522$.

9. Ogasawara S, Fujii Y, Kaneko MK, Oki H, Sabit H, Nakada M, Suzuki H, Ichimura K, Komori T, and Kato Y: Establishment of anti-human ATRX monoclonal antibody AMab-6. Monoclon Antib Immunodiagn Immunother 2016; 35:254-258.

10. Fujii Y, Ogasawara S, Oki H, Liu X, Kaneko MK, Takano S, and Kato Y: A high-sensitive HMab-2 specifically detects IDH1-R132H, the most common IDH mutation in gliomas. Biochem Biophys Res Commun 2015;466:733-739.

11. Liu X, Ogasawara S, Kaneko MK, Oki H, Hozumi Y, Goto K, Takagi M, and Kato Y: A novel monoclonal antibody SMab-2 recognizes endogenous IDH2-R172S of chondrosarcoma. Biochem Biophys Res Commun 2015;459: 636-642.

12. Kato Kaneko M, Liu X, Oki H, Ogasawara S, Nakamura T, Saidoh N, Tsujimoto Y, Matsuyama Y, Uruno A, Sugawara M, Tsuchiya T, Yamakawa M, Yamamoto M, Takagi M, and Kato Y: Isocitrate dehydrogenase mutation is frequently observed in giant cell tumor of bone. Cancer Sci 2014;105:744-748.

13. Liu X, Kato Y, Kaneko MK, Sugawara M, Ogasawara S, Tsujimoto Y, Naganuma Y, Yamakawa M, Tsuchiya T, and Takagi M: Isocitrate dehydrogenase 2 mutation is a frequent event in osteosarcoma detected by a multi-specific monoclonal antibody MsMab-1. Cancer Med 2013;2:803-814.

14. Ogasawara S, Kaneko MK, Tsujimoto Y, Liu X, and Kato Y: Multi-specific monoclonal antibody MsMab-2 recognizes IDH1-R132L and IDH2-R172M mutations. Monoclon Antib Immunodiagn Immunother 2013;32:377-381. 
15. Kato $\mathrm{Y}$, and Kaneko MK: Generation of a novel monoclonal antibody WMab-1 specific for IDH2-R172W mutation. Biochem Biophys Res Commun 2013;433:374-378.

16. Kaneko MK, Morita S, Tsujimoto Y, Yanagiya R, Nasu K, Sasaki H, Hozumi Y, Goto K, Natsume A, Watanabe M, Kumabe T, Takano S, and Kato Y: Establishment of novel monoclonal antibodies KMab-1 and MMab-1 specific for IDH2 mutations. Biochem Biophys Res Commun 2013; 432:40-45.

17. Fujii Y, Kaneko MK, and Kato Y: MAP tag: A novel tagging system for protein purification and detection. Monoclon Antib Immunodiagn Immunother 2016;35:293-299.

18. Ogasawara S, Kaneko MK, and Kato Y: LpMab-19 recognizes sialylated O-glycan on Thr76 of human podoplanin. Monoclon Antib Immunodiagn Immunother 2016;35:245-253.

19. Honma R, Kaneko MK, Ogasawara S, Fujii Y, Konnai S, Takagi M, and Kato Y: Specific detection of dog podoplanin expressed in renal glomerulus by a novel monoclonal antibody PMab-38 in immunohistochemistry. Monoclon Antib Immunodiagn Immunother 2016;35:212-216.

20. Honma R, Ogasawara S, Kaneko M, Fujii Y, Oki H, Nakamura T, Takagi M, Konnai S, and Kato Y: PMab-44 detects bovine podoplanin in immunohistochemistry. Monoclon Antib Immunodiagn Immunother 2016 [Epub ahead of print]; DOI: 10.1089/mab.2016.0016.

21. Hochuli E, Bannwarth W, Dobeli H, Gentz R, and Stuber D: Genetic approach to facilitate purification of recombinant proteins with a novel metal chelate adsorbent. Nat Biotechnol 1988;6:1321-1325.

22. Field J, Nikawa J, Broek D, Macdonald B, Rodgers L, Wilson IA, Lerner RA, and Wigler M: Purification of a RAS-responsive adenylyl cyclase complex from Saccharomyces cerevisiae by use of an epitope addition method. Mol Cell Biol 1988;8:2159-2165.

23. Evan GI, Lewis GK, Ramsay G, and Bishop JM: Isolation of monoclonal antibodies specific for human c-myc protooncogene product. Mol Cell Biol 1985;5:3610-3616.

24. Oki H, Honma R, Ogasawara S, Fujii Y, Liu X, Takagi M, Kaneko MK, and Kato Y: Development of sensitive monoclonal antibody PMab-2 against rat podoplanin. Monoclon Antib Immunodiagn Immunother 2015;34:396-403.

25. Kato Y, Fujita N, Kunita A, Sato S, Kaneko M, Osawa M, and Tsuruo T: Molecular identification of Aggrus/T1alpha as a platelet aggregation-inducing factor expressed in colorectal tumors. J Biol Chem 2003;278:51599-51605.

26. Kato Y, Sasagawa I, Kaneko M, Osawa M, Fujita N, and Tsuruo T: Aggrus: A diagnostic marker that distinguishes seminoma from embryonal carcinoma in testicular germ cell tumors. Oncogene 2004;23:8552-8556.

27. Kato Y, Kaneko M, Sata M, Fujita N, Tsuruo T, and Osawa $\mathrm{M}$ : Enhanced expression of Aggrus (T1alpha/podoplanin), a platelet-aggregation-inducing factor in lung squamous cell carcinoma. Tumor Biol 2005;26:195-200.

28. Kato Y, Kaneko MK, Kuno A, Uchiyama N, Amano K, Chiba Y, Hasegawa Y, Hirabayashi J, Narimatsu H, Mis- hima $\mathrm{K}$, and Osawa M: Inhibition of tumor cell-induced platelet aggregation using a novel anti-podoplanin antibody reacting with its platelet-aggregation-stimulating domain. Biochem Biophys Res Commun 2006;349:1301-1307.

29. Kato Y, Vaidyanathan G, Kaneko MK, Mishima K, Srivastava N, Chandramohan V, Pegram C, Keir ST, Kuan CT, Bigner DD, and Zalutsky MR: Evaluation of antipodoplanin rat monoclonal antibody NZ-1 for targeting malignant gliomas. Nucl Med Biol 2010;37:785-794.

30. Kato Y, and Kaneko MK: A cancer-specific monoclonal antibody recognizes the aberrantly glycosylated podoplanin. Sci Rep 2014;4:5924.

31. Kato Y, Kunita A, Abe S, Ogasawara S, Fujii Y, Oki H, Fukayama M, Nishioka Y, and Kaneko MK: The chimeric antibody chLpMab-7 targeting human podoplanin suppresses pulmonary metastasis via ADCC and CDC rather than via its neutralizing activity. Oncotarget 2015;6:36003-36018.

32. Kato Y, Ogasawara S, Oki H, Goichberg P, Honma R, Fujii Y, and Kaneko MK: LpMab-12 established by CasMab technology specifically detects sialylated O-glycan on Thr52 of platelet aggregation-stimulating domain of human podoplanin. PLoS One 2016;11:e0152912.

33. Kato Y, Ogasawara S, Oki H, Honma R, Takagi M, Fujii Y, Nakamura T, Saidoh N, Kanno H, Umetsu M, Kamata S, Kubo H, Yamada M, Sawa Y, Morita K, Harada H, Suzuki $\mathrm{H}$, and Kaneko MK: Novel monoclonal antibody LpMab17 developed by CasMab technology distinguishes human podoplanin from monkey podoplanin. Monoclon Antib Immunodiagn Immunother 2016;35:109-116.

34. Sato C, Kim JH, Abe Y, Saito K, Yokoyama S, and Kohda D: Characterization of the N-oligosaccharides attached to the atypical Asn-X-Cys sequence of recombinant human epidermal growth factor receptor. J Biochem 2000;127:65-72.

35. Watanabe M, Terasawa K, Kaneshiro K, Uchimura H, Yamamoto R, Fukuyama Y, Shimizu K, Sato TA, and Tanaka K: Improvement of mass spectrometry analysis of glycoproteins by MALDI-MS using 3-aminoquinoline/ alpha-cyano-4-hydroxycinnamic acid. Anal Bioanal Chem 2013;405:4289-4293.

Address correspondence to: Dr. Yukinari Kato New Industry Creation Hatchery Center Tohoku University 2-1 Seiryo-machi, Aoba-ku Sendai Miyagi 980-8575 Japan

E-mail: yukinari-k@bea.hi-ho.ne.jp

Received: December 21, 2016 Accepted: February 21, 2017 